\title{
5-Aminolevulinic acid and the hepatic oxidative stress in the early phase of experimental hexachlorobenzene intoxication
}

\author{
Tânia Cristina Higashi Sawada*, Vanessa Vitoriano da Silva, Sonia Barros, Cristina Dislich Röpke, \\ Silvia Berlanga de Moraes Barros
}

Departamento de Análises Clínicas e Toxicológicas, Faculdade de Ciências Farmacêuticas, Universidade de São Paulo

*Correspondência:

T. C. H. Sawada

Departamento de Análises Clínicas e

Toxicológicas

Faculdade de Ciências Farmacêuticas

- USP

Av. Lineu Prestes, 580

05508-900 - São Paulo - SP

E-mail: tsawada@usp.br
This work evaluated the levels of 5-aminolevulinic acid (ALA) in the liver of rats exposed to different doses of $H C B$ (25,50, and $100 \mathrm{mg} / \mathrm{kg} \mathrm{b.w.} \mathrm{for} 4$ weeks) and correlated them with lipid peroxidation parameters. Levels of ALA were determined by highpressure liquid chromatography after derivatization with acetylacetone and formaldehyde, followed by fluorescence detection. The methodology was carefully validated, nonetheless hepatic levels of ALA in all animals treated or not were below the detection limit of the method (2.27mg of ALA/g liver). On the other hand, lipid peroxidation, evaluated as thiobarbituric acid reactants production and chemiluminescence was found significantly increased in the livers of all treated rats, in comparison with control values $(p<0.05)$. These results suggest that the hepatic oxidative stress observed in animals following HCB treatment may not necessarily be associated with increased levels of ALA in the liver. Another possibility is that increased levels of ALA in the liver, even below the detection limit of the method are sufficient to induce hepatic oxidative stress.

\section{INTRODUCTION}

Hexachlorobenzene (HCB) has been used in the past as a fungicide for crop protection. Nowadays, it can be released in the environment as a by-product of the chemical industry and it may be present as impurity in the formulation of several widely used pesticides (Jacoff et al., 1986).

Between 1955 and 1959 many people in southeastern Turkey developed chronic porphyria after consuming wheat that had been treated with HCB (Schmid, 1960). HCB was shown to be hepatotoxic; effects in the liver range from hepatocellular enlargement to severe disturbance of the haem synthesis, resulting in accumulation of porphyrins in the liver and their massive excretion in the urine, as consequence of the inhibition of hepatic uroporphyrinogen-decarboxylase activity (UROD) (Elder et al., 1976; Börge et al., 1979).

Reactive oxygen species (ROS) have been proposed to play an important role in the pathogenesis of the porphyria caused by polyhalogenated aromatic hydrocarbons, such as HCB (Ferioli et al., 1984; Almeida et al., 1997; Billi de Catabbi et al., 1997). Several authors 
have shown an increase of lipid peroxidation in the liver of rats treated with different doses of HCB. According to Billi de Catabbi et al. (1997), the increase in lipid peroxidation found in the liver of rats treated with $1 \mathrm{~g} / \mathrm{kg}$ b.w. of $\mathrm{HCB}$ reflects rises in ROS levels. Almeida et al. (1997) postulated this higher lipid peroxidation could be a consequence of increased levels of superoxide anion produced by cytochrome P450 (Urquhart, Elder, 1987; Visser et al., 1989; Almeida et al., 1997). Additionally, ROS could also play some role in the inhibitory process of UROD, by formation of an URO-D inhibitor (De Matteis, 1988).

Uroporphyrinogen-decarboxylase is the key enzyme of the heme metabolic pathway, which is blocked in cases of porphyria, not only in humans but also in the experimental HCB-induced model. This blockage impairs the regulation of the heme pathway as observed in lead intoxication (Elder et al., 1976; Hindmarsh, 1986) when ALA-dehydratase is inhibited, leading to the increase of ALA excretion in urine (Wainstok De Calmanovici et al., 1986).

ALA has been proposed as an endogenous prooxidant in these pathological conditions (Bechara et al., 1996). Some authors reported the involvement of ROS produced during autooxidation of enolic ALA in rat liver mitochondria as an explanation to the pathophysiology of acute intermittent porphyria (Hermes-Lima et al., 1991; Monteiro et al., 1986; Vercesi et al., 1994). This work sought to evaluate lipid peroxidation parameters in the liver of rats exposed to different doses of $\mathrm{HCB}$ and their correlation with the levels of ALA, considering this molecule as a potent prooxidant with capacity to induce oxidative stress.

\section{MATERIAL AND METHODS}

\section{Animals and treatment}

Male Wistar rats weighing 180-200 g were fed rat chow (Purina, São Paulo, Brasil) ad libitum. HCB dissolved in corn oil by sonication, was administered by gavage (25, 50 and $100 \mathrm{mg} / \mathrm{kg}$ body wt.) 5 days a week for 4 weeks.

Control animals received isovolumetric amount of corn oil $\left(\right.$ Mazola $\left.^{\circledR}\right)$. Animals were euthanized 24 hours after the last dose by cervical dislocation.

\section{5-aminolevulinic acid (ALA) determination by HPLC Chemicals}

5-Aminolevulinic acid hydrochloride (ALA) and $N$ -[2-hydroxyethyl]piperazine- $N^{\prime}$-[2-ethanesulfonic acid] (HEPES) were purchased from Sigma (St. Louis, MO, USA), formaldehyde, acetylacetone, methanol, 2- mercaptoethanol and trichloroacetic acid were bought from Merck (Darmstadt, Germany). The water used was bidistilled and subsequently deionized.

\section{Chromatographic conditions}

The HPLC system consisted of a Model 510 Waters pump coupled with a 1046 A Hewlett Packard fluorescence detector and a SP4600 Data Jet Thermo Separation integrator. The analytical conditions were as follow: mobile phase, methanol-water $(500: 500, \mathrm{~V}: \mathrm{V})$; analytical column, Supelcosil LC-18 Supecol (150 x 4.6 $\mathrm{mm}$ I.D., $5 \mathrm{~mm}$ particle diameter); flow-rate, $0.5 \mathrm{~mL} / \mathrm{min}$; and injection volume, $20 \mathrm{~mL}$. The excitation and emission wavelengths were set at 370 and $460 \mathrm{~nm}$, respectively.

\section{Standard solution}

Stock standard solution of ALA was prepared by dissolving $5 \mathrm{mg}$ of 5 -aminolevunilic acid in $50 \mathrm{~mL}$ of deionized water and storing at $4{ }^{\circ} \mathrm{C}$. This solution was diluted to give appropriate concentrations of ALA.

\section{Sample Collection}

Liver (1g) non-perfused was homogenized (1:3 w:v) in $10 \mathrm{mM} N$-[2-hydroxyethyl]piperazine- $N$ '-[2ethanesulfonic acid] buffer $\mathrm{pH} 7.0$ with a Teflon pestle in a tight-fitting glass vessel and centrifuged for $5 \mathrm{~min}$ at $1000 \mathrm{x} \mathrm{g}$ at $4{ }^{\circ} \mathrm{C}$. The pellet was discarded and the supernatant was used for ALA determination.

\section{ALA determination}

A modification of the method described by Okayama et al. (1990) was employed, replacing 2iodoacetamide by 2 -mercaptoethanol to prevent thiol formation.

Liver homogenates supernatant $(250 \mathrm{~mL})$, as according described above, was added with $0.06 \mathrm{M} 2$ mercaptoethanol $(15 \mathrm{~mL})$ and, after two minutes, trichloroacetic acid $35 \%(60 \mathrm{~mL})$. The mixture was centrifuged at $1600 \mathrm{x}$ g for $10 \mathrm{~min}$, and the supernatant $(25 \mathrm{~mL})$ was mixed with acetylacetone $(100 \mathrm{~mL})$, acetic acid $(625 \mathrm{~mL})$ and formaldehyde solution $10 \%(250 \mathrm{~mL})$. The mixture was mixed in vortex, heated at $100{ }^{\circ} \mathrm{C}$ in a multiblock heater for $10 \mathrm{~min}$, cooled in an ice-cold water bath to stop the derivatization reaction in a glass to the dark conditions, and filtered through a $0.22 \mathrm{~mm}$ filter. The filtrate $(20 \mathrm{~mL})$ was injected into the HPLC system.

\section{Liver lipid peroxidation parameters}

\section{Sample preparation}

Animals were euthanized by cervical dislocation. 
After opening the peritoneal cavity was done the excision of a sample for the ALA determination, the liver was perfused with cold $0.9 \% \mathrm{NaCl}$ by portal vein, it was removed, weighed and homogenized $(1: 3 \mathrm{w} / \mathrm{v})$ in $140 \mathrm{mM}$ $\mathrm{NaCl} 40 \mathrm{mM}$ Phosphate buffer $\mathrm{pH} 7.4$ with a Teflon pestle in a tight-fitting glass vessel and centrifuged for $20 \mathrm{~min}$ at $1000 \mathrm{x}$ g at $4{ }^{\circ} \mathrm{C}$. The supernatant was used for lipid peroxidation evaluation as thiobarbituric acid reactants (TBARs) and chemiluminescence (CL).

\section{Thiobarbituric acid reactants (TBARs) measurement}

The supernatant of liver homogenates was incubated at $37^{\circ} \mathrm{C}$ in a shaker water bath, diluted $(1: 3 \mathrm{v} / \mathrm{v})$ in $0.1 \mathrm{M}$ potassium phosphate buffer $\mathrm{pH}$ 7.0. After a 2 hour incubation, samples were precipitated with 5\% TCA and TBARs determined in the supernatant according to Junqueira et al. (1986).

\section{Chemiluminescence $(C L)$ emission}

The supernatant of liver homogenates was diluted $(1: 8 \mathrm{v} / \mathrm{v})$ in $140 \mathrm{mM} \mathrm{NaCl} 40 \mathrm{mM}$ phosphate buffer $\mathrm{pH} 7.4$ and incubated for $30 \mathrm{~min}$ at $37^{\circ} \mathrm{C}$ in a shaker bath. Chemiluminescence of the incubated liver homogenates $(3 \mathrm{~mL})$ was measured in a Packard $1700 \mathrm{R}$ liquid scintillation analyzer using the single photon monitor mode at $25{ }^{\circ} \mathrm{C}$. The values were expressed as cpm per gram of tissue (Boveris et al., 1983).

\section{Protein determination}

Protein concentration was estimated employing the biuret reagents (Layne, 1957).

\section{Statistics}

Mean values were compared by ANOVA followed by Tukey's test. Differences were considered statistically significant when $p$ values were less than 0.05 .

\section{RESULTS}

\section{ALA analysis}

\section{Validation of method}

Typical chromatograms of the ALA derivative (200 mg/ L ALA standard solution), a liver sample to which ALA has been added to prepare $200 \mathrm{mg} / \mathrm{L}$ of ALA in the homogenate and liver sample from rats treated with 100 $\mathrm{mg}$ of $\mathrm{HCB} / \mathrm{kg}$ body wt. are show in Figure 1.
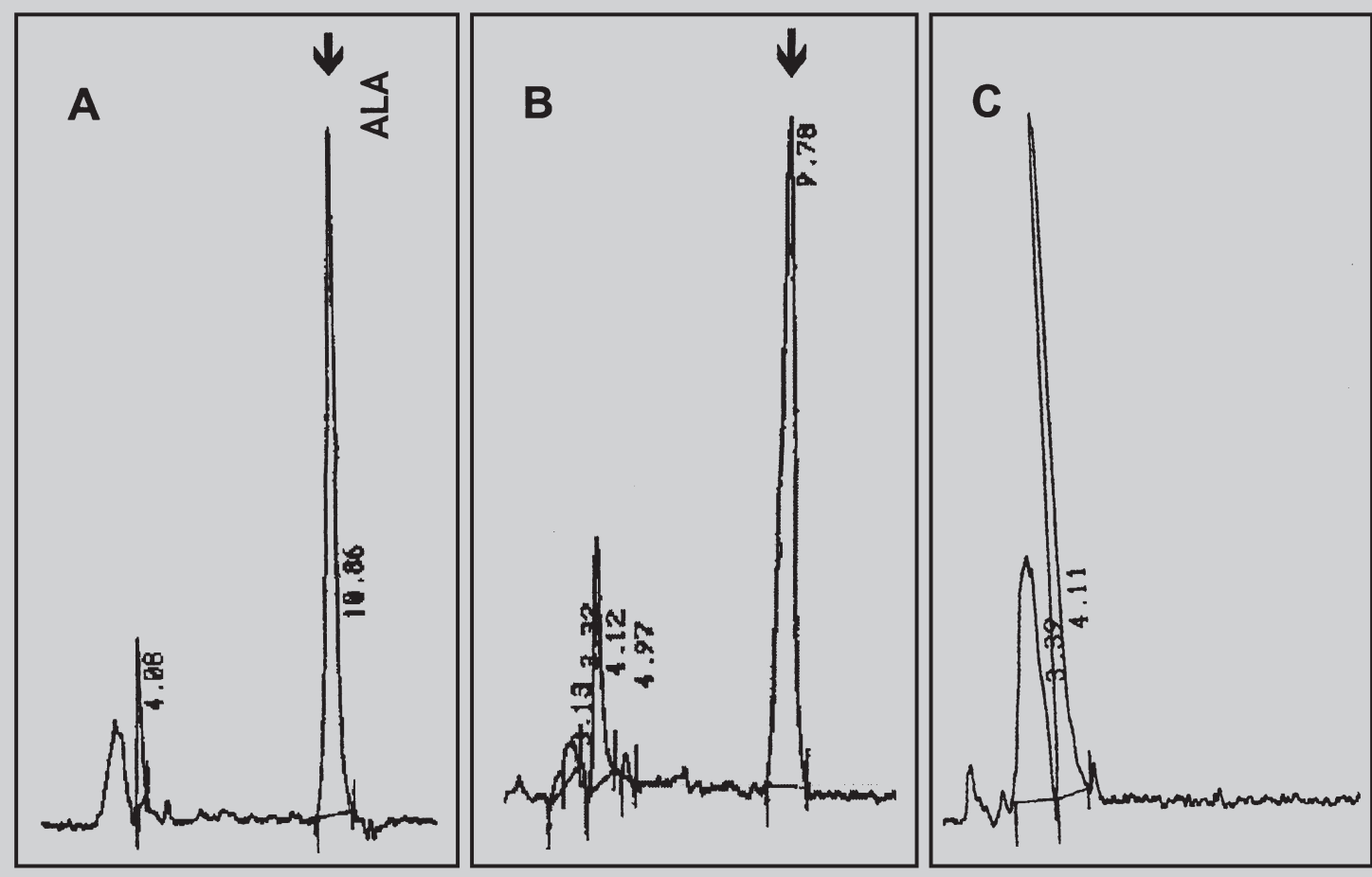

FIGURE 1 - HPLC chromatogram of ALA with fluorescence detector. (A) Chromatogram of 5-aminolevulinic acid (ALA) in standard solution (200 mg/ L, left); (B) liver homogenate + ALA (prepared at $200 \mathrm{mg} / \mathrm{L}$, middle); (C) liver sample from rats treated with HCB $(100 \mathrm{mg} / \mathrm{kg}$ body wt, right). Arrow = peak of ALA derivative. Retention of time: $15 \mathrm{~min}$ (ALA). Chromatographic conditions in the text. 
TABLE I - Lipid peroxidation parameters liver of non-treated and HCB-treated rats

\section{TBARS (nmol/mg of protein/120 min)}

\begin{tabular}{ll}
\hline Control rats & $1.49 \pm 0.27(8)$ \\
$25 \mathrm{mg}$ of $\mathrm{HCB} / \mathrm{kg}$ & $2.85 \pm 0.57(8) *$ \\
$50 \mathrm{mg}$ of $\mathrm{HCB} / \mathrm{kg}$ & $2.55 \pm 0.61(6) *$ \\
$100 \mathrm{mg}$ of $\mathrm{HCB} / \mathrm{kg}$ & $2.85 \pm 0.59(8) *$ \\
\hline
\end{tabular}

Chemiluminescence (counts $/ \mathrm{min} .10^{6} / \mathrm{mg}$ of protein

$\begin{array}{ll}\text { Control rats } & 1.5 \pm 0.7(6) \\ 25 \mathrm{mg} \text { of } \mathrm{HCB} / \mathrm{kg} & 2.8 \pm 1.2(6) * \\ 50 \mathrm{mg} \text { of } \mathrm{HCB} / \mathrm{kg} & 3.5 \pm 1.6(6) * \\ 100 \mathrm{mg} \text { of } \mathrm{HCB} / \mathrm{kg} & 3.7 \pm 1.6(6) *\end{array}$

Values represent the means \pm SD. The number in parenthesis represents the number of animals per group

(*) Significantly different from control rats $(\mathrm{p}<0.05)$

The concentration of ALA in the standard solution $(12.5-200 \mathrm{mg} / \mathrm{L})$ linearly correlated to the fluorescence intensity given by peak areas $(\mathrm{r}=0.997)$. The calibration curve for standard ALA can be represented by the equation $y=-9921+1070.5 x$, and that of the ALA liver homogenate spiked with authentic ALA, by the equation $\mathrm{y}=-12591.2+1223 \mathrm{x}(\mathrm{r}=0.998)$.

The reproducibility of ALA quantification was tested in the liver samples with addition of ALA standard solution. The variation coefficients ranged from 2.4 to $8.9 \%$ for interday assay and $7 \%$ and from $17.5 \%$ for intraday assay. The recovery of ALA added to liver homogenate $(12.5,50$ and $200 \mathrm{mg} / \mathrm{L}$ ) was $100 \%$. The detection limit was $6.25 \mathrm{mg} / \mathrm{L}$ or $0.74 \mu \mathrm{mol} / 20 \mathrm{~mL}$ of ALA.

ALA concentration in liver homogenate of both control and HCB-treated $(25,50$ and $100 \mathrm{mg} / \mathrm{kg}$ body wt) were under the detection limit of the method $(2.27 \mathrm{mg}$ of ALA/g liver).

\section{Lipid peroxidation parameters in the liver of control and HCB-treated rats}

All animals treated with HCB showed increased levels of TBARs and CL, as compared to control animals (Table I).

\section{DISCUSSION}

In order to investigate the role of ALA in HCBinduced liver oxidative stress, we validated the method proposed by Okayama et al. (1990) for ALA determination in the hepatic tissue of rats. The detection limit obtained was $0.74 \mu \mathrm{mol} /$ injection, or $2.27 \mu \mathrm{g} / \mathrm{g}$ of liver, and the high recovery percentage (100\%) shows that ALA was not lost during the extraction procedure.
The validated method was subsequently employed to determine ALA concentration in hepatic tissue of nontreated and HCB-treated animals $(25,50$ and $100 \mathrm{mg}$ of $\mathrm{HCB} / \mathrm{kg}$ b.w.). The results indicated levels of ALA lower than $2.27 \mathrm{mg} / \mathrm{g}$ of liver, below the detection limit of the method. According to McGillion et al. (1974), quantification of ALA in hepatic tissue of control animals by isotopic methods resulted in $0.06 \mathrm{mg} / \mathrm{g}$ of liver. This value is much below our detection limit of ALA and could explain why ALA was not detected in the controls. The fast elimination kinetics of ALA could be another determinant. According to McGillion et al. (1974), ALA could not be found in hepatic tissue of rats after 24 hours of an intraperitoneal injection. Considering that the animals were sacrificed after 24 hours of exposure to $\mathrm{HCB}$, we decided to further assess this possibility. Rats were exposed to a high concentration of HCB $(1 \mathrm{~g} / \mathrm{kg}$ b.w.) for 3 days, enough time to induce hepatic lipid peroxidation, as shown by Almeida and Barros (1994). Even though animals were sacrificed after 30 minutes of the last the administration of HCB, ALA levels in the liver remained below the detection limit (results not shown).

Almeida et al. (1997) demonstrated that superoxide anion production by the endoplasmic reticulum is increased in rats treated with daily doses of $25 \mathrm{mg}$ of $\mathrm{HCB} /$ $\mathrm{kg}$ b.w. for 30 consecutive days. These increased levels of superoxide anion could lead to the production of hydrogen peroxide by Fenton reaction. According to De Matteis et al. (1988), $\mathrm{H}_{2} \mathrm{O}_{2}$ can be responsible for the oxidation of uroporphyrinogen, with the production of a sufficiently stable oxidative derivative, which in turn could act as inhibitor of URO-D.

Although we did not demonstrate an increase of ALA in the liver of HCB-treated animals, our results 
indicate an oxidative stress condition in the liver of these animals (Table 1). Wainstok De Calmanovici et al. (1984) demonstrated a decrease in the activity of hepatic URO-D after 4 weeks in rats treated with $1 \mathrm{~g}$ of $\mathrm{HCB} / \mathrm{kg}$ b.w., however, ALA levels were found increased only after 6 weeks of treatment. The results reinforce the hypothesis that oxidative stress actually precedes ALA accumulation, suggesting that, at an earlier time of exposure, other factors, such as induction of cytochrome P450 (CYP450) (Smith et al., 1990; Franklin et al., 1997, Almeida et al, 1997), followed by increase in superoxide anion production (Almeida et al, 1997), may contribute to the observed oxidative stress condition in the liver. Nevertheless, one cannot exclude the possibility of ALA participation as an inducer of hepatic oxidative stress at a later phase of HCB exposure.

\section{RESUMO}

\section{Ácido delta-aminolevulinico e estresse oxidativo hepático na fase inicial da intoxicação experimental por hexaclorobenzeno}

Este trabalho avaliou os niveis de ácido deltaaminolevulínico (ALA) em fígado de ratos expostos a diferentes doses de hexaclorobenzeno (HCB) $(25,50 \mathrm{e}$ $100 \mathrm{mg} / \mathrm{kg}$ de peso corpóreo) durante 4 semanas e correlacionou com os parâmetros de peroxidação lipídica. Os niveis de ALA foram determinados por cromatografia líquida de alta eficiência após derivatização com acetilacetona e formaldeído, seguida de detecção de fluorescência. A metodologia foi cuidadosamente validada, apesar disso, os niveis hepáticos de ALA em todos os animais tratados ou não foram abaixo do limite de detecção do método $(2,27 \mathrm{mg}$ de $\mathrm{ALA} / \mathrm{g}$ de fígado). Por outro lado, para a peroxidação lipídica, avaliada como produção de reagentes ao ácido tiobarbitúrico e quimiluminescência, os resultados foram significativamente elevados em todos os animais tratados em comparação com os do grupo controle $(p<0,05)$. Estes resultados sugerem que o estresse oxidativo hepático observado nos animais após tratamento com HCB não deve necessariamente estar associado com o aumento das concentrações de ALA no fígado. Uma outra possibilidade seria o aumento nos níveis de ALA no figado, mesmo que abaixo do limite de detecção do método, sendo suficiente para induzir estresse oxidativo hepático.

UNITERMOS: Hexaclorobenzeno. Estresse oxidativo. Ácido delta-aminolevulínico

\section{ACKNOWLEDGEMENTS}

This study was supported by research grants from FAPESP process number 97/05929-3.

\section{REFERENCES}

ALMEIDA, M. G.; BARROS, S. B. M. Oxidative stress: Possible mechanism for hexachlorobenzene hepatoxicity. In: MEETING OF THE INTERNATIONAL SOCIETY FOR THE STUDY OF XENOBIOTICS, 5., 1994. Abstracts. North Carolina: ISSX, 1994. p.257.

ALMEIDA, M. G.; FANINI, F.; DAVINO, S. C.; AZNAR, A. E.; KOCH, O. R.; BARROS, S. B. M. Pro - and - antioxidant parameters of rat liver after short term exposure to hexachlorobenzene. Hum. Exp. Toxicol., Basingstoke, v.16, p.257-261, 1997.

BECHARA, E. J. H. Oxidative stress in acute intermittent porphyria and lead poisoning may be triggered by 5 aminolevulinic. Braz. J. Med. Biol. Res., Ribeirão Preto, v.29, p.841-851, 1996.

BILLI DE CATABBI, S.; STERIN-SPEZIALE, N.; FERNANDEZ, M. C.; MINUTOLO, C.; ALDONATTI, C.; SAN MARTIN DE VIALE, L. Time course of hexachlorobenzene-induced alterations of lipid metabolism and their relation to porphyria. Int. $J$. Biochem. Cell Biol., Oxford, v.29, p.335-344, 1997.

BÖRGE, A.; KOSS, G.; KORANSKY, W.; NAUMANN, R.; FRENZEL, H. Rat liver alterations after chronic treatment with HCB. Virchows Arch. A. Pathol. Anal. Histol., Amsterdam, v.382, p.127-137, 1979.

BOVERIS, A.; FRAGA, C. G.; VARSAVSKY, A. I.; KOCH, O. R. Increased chemiluminescence and superoxide production in the liver of chronically ethanol-treated-rats. Arch. Biochem. Biophys., New York, v.227, p.534-541, 1983.

DE MATTEIS, F.; HARVEY, C.; REED, C.; HEMPENIUS, R. Increased oxidation of uroporphyrinogen by an inducible liver microssomal system. Possible relevance to drug-induced uroporphyria. Biochem. J., London, v.250, p.161-169, 1988.

ELDER, G. H.; EVANS, J. O.; MATLIN, S. A. The effect of porphyrinogenic compound hexachlorobenzene on the activity of uroporphyrinogen decarboxylase in rat liver. Clin. Sci. Mol.Med., Oxford, v.51, p.71-80, 1976. 
FERIOLI, A.; HARVEY, C.; DE MATTEIS, F. Druginduced accumulation of uroporphyrin in chicken hepatocyte cultures. Biochem. J., London, v. 224, p.769$777,1984$.

FRANKLIN, M. R.; PHILLIPS, J. D.; KUSHNER, J. P. Cytochrome P-450 induction, uroporphyrinogen decarboxylase depression, porphyrin accumulation and excretion, and gender influence in a 3 week rat model of porphyria cutanea tarda. Toxicol. Appl. Pharmacol., Orlando, v.147, p.289-299, 1997.

LAYNE, E. Spectrophotometric and turbidimetric methods for measuring proteins. In: COLOWICK, S. P.; KAPLAN, N.O., eds. Methods in Enzymology. New York: Academic Press, 1957. v.3, p.447-454.

HERMES-LIMA, M.; VALLE, V. G. R.; VERCESI, A. E.; BECHARA, E. J. H. Damage to rat liver mitochondria promoted by d-aminolevulinic acid-generated reactive oxygen species: connections with acute intermittent porphyria and lead-poisoning. Biochim. Biophys. Acta, Amsterdam, v.1056, p.57-63, 1991.

HINDMARSH, J. T. Porphyrias: recent advances. Clin. Chem., Winston Salem, v.32, p.1263, 1986.

JACOFF, F. S.; SCARBERRY, R.; ROSA, D. Source assessment of hexachlorobenzene from the organic chemical manufacturing industry. In: MORRIS, C. R., CABRAL, J. R. P., eds. Hexachlorobenzene. Lion: International Agency for Research on Cancer, 1986. p. 31-37. [Proceedings of an International Symposium].

JUNQUEIRA, V. B. C.; SIMIZU, K.; VIDELA, L. A.; BARROS, S. B. M. Dose-dependent study of the effects of acute lindane administration of rat liver superoxide anion production, antioxidant enzyme activities and lipid peroxidation. Toxicology, Shannon, v.41, p.193-204, 1986.

MCGILLION, F. B.; THOMPSON, G. G.; GOLDBERG, A. Tissue uptake of $\delta$-aminolevulinic acid. Biochem. Pharmacol., New York, v.24, p.299-301, 1974.

MONTEIRO, H. P.; ABDALLA, D. S. P.; FALJONIALÁRIO, A.; BECHARA, E. J. H. Generation of active species during coupled autoxidation of oxyhemoglobin and d-aminolevulinic acid. Biochim. Biophys. Acta, Amsterdam, v.881, p.100-106, 1986.
OKAYAMA, A.; FUJI, S.; MIURA, R. Optimized fluorometric determination of urinary $\delta$-aminolevulinic acid by using pre-column derivatization, and identification of liquid chromatography. J. Chromatogr. B.: Biomed. Sci. Appl., Amsterdam, v.654, p.165-169, 1990.

SCHMID, R. Cutaneous porphyria in Turkey. N. Engl. J. Med., Boston, v.263, p.397-398, 1960.

SMITH, A. G.; MATTEIS, F. Oxidative injury mediated by hepatic cytochrome P-450 system in conjuction with cellular iron. Effects on the pathway of heme biosynthesis. Xenobiotica, London, v.20, p.865-877, 1990.

URQUHART, A. J.; ELDER, G. H. Hexachlorobenzeneinduced oxygen activation by mouse liver microsomes: comparison with phenobarbitone and 20methylcholanthrene. Biochem. Pharmacol., New York, v.36, p.3795-3796, 1987.

VERCESI, A. E.; CASTILHO, R. F.; MEINICKE, A. R.; VALLE, V. G. R.; HERMES-LIMA, M.; BECHARA, E. J. H. Oxidative damage of mitochondria induced by 5 aminolevulinic acid: role of $\mathrm{Ca}+2$ ions and membrane protein thiols. Biochim. Biophys. Acta, Amsterdam, v.1188, p.86-92, 1994.

VISSER, O.; VAN DER BERG, J. W. O.; EDIXHOVENBOSDIJK, A.; KOOLE-LESUIS, R.; RIETVELD, T.; WILSON, J. H. P. Development of hexachlorobenzene porphyria in rats time sequence and relationships with lipid peroxidation. Food Chem. Toxicol., Oxford, v.27, p.317-321, 1989.

WAINSTOK DE CALMANOVICI, R.; RIOS DE MOLINA, M.; TAIRA DE YAMASATO, M. C.; TOMIO, J. M.; SAN MARTIN DE VALLE, L. C. Mechanism of hexachlorobenzene-induced porphyria in rats. Effect of phenobarbitone pretreatment. Biochem. J., London, v.218, p.753-763, 1984.

WAINSTOK DE CALMANOVICI, R.; RIOS DE MOLINA M. D. C.; VILA, M. C.; SAN MARTIN DE VIALE, L. C. Studies on the role of iron in the alterations observed in hexachlorobenzene-induced porphyria. IARC Sci Publ., v.77, p.497-503, 1986.

Recebido para publicação em 29 de setembro de 2003. 